\title{
A BIOLÓGIAI TERÁPIA ALKALMAZÁSA ÍZÜLETI GYULLADÁSOKBAN
}

\section{USE OF BIOLOGICAL THERAPY FOR ARTHRITIS}

\author{
Poór Gyula \\ az MTA levelező tagja, egyetemi tanár, főigazgató \\ Országos Reumatológiai és Fizioterápiás Intézet, Budapest, Semmelweis Egyetem, Budapest \\ poor.gyula@orfi.hu
}

\section{ÖSSZEFOGLALÁS}

A dolgozat áttekinti az artritiszek jelentőségét és különböző típusait. Foglalkozik a kórképekben használt biológiai készítményekkel, a TNF-alfa és interleukin inhibitorokkal, valamint a T- és B-sejt-gátlókkal. Vázolja a hazai centrumszintű szakorvosi ellátás struktúráját, a finanszírozást, bemutatja az ellátás eredményeit és jövőbeli lehetőségeit.

\section{ABSTRACT}

The paper reviews the importance and different types of arthritides. It deals with biologicals used in arthritis, i.e. TNF-alpha and interleukin inhibitors as well as blockers of T and B cells. The publication outlines the structure and financing of the centre-based specialist patient care system, shows its results and the future therapeutic possibilities.

Kulcsszavak: artritiszek jelentősége és típusai, biológiai készítmények (biologikumok), hazai centrumszintű ellátás, eredmények, finanszírozás, kitekintés

Keywords: importance and types of arthritides, available biologicals, centre-based patient care in Hungary, results, financing, outlook

A végtagokon és a gerincen zajló ízületi gyulladások (artritiszek) jelentősége az utóbbi évtizedben a mozgásszervi betegekkel foglalkozó szakemberek körében érzékelhetően felértékelődött. Ennek oka a degeneratív kórképekhez (artrózis, oszteoporózis, lágyrész-reumatizmus) képest kisebb, mintegy 150 ezres betegszám ellenére abban rejlik, hogy ezen betegségek jóval korábban, többnyire a fiatal felnőttkorban vagy éppen gyermek- és serdülőkorban jelentkeznek, és súlyosabb mozgásszervi károsodásokat idéznek elö, tehát a munkaképességet és az életminőséget hosszú távon és komolyan veszélyeztetik. Ugyanakkor kihatnak 
az életkilátásokra is, hiszen számosan ezek közül magasabb mortalitással járnak együtt. Szerepüket az is növeli, hogy az alap-, az alkalmazott és a klinikai kutatások fókuszába kerültek, ami a korábbiakhoz képest számos fontos gyakorlati következménnyel is járt. A szemléletváltást jellemző kulcsszavak a korai diagnosztika és prognosztika, az állapotfelmérések, valamint a korai agresszív kezelés, és mindezek folyományaképpen új, korábban irreálisnak tünő terápiás célkitűzések megvalósítása, mint például a munkaképesség megtartása. A gyógyítás folyamatában a beteg maga is kulcsszereplővé vált.

\section{AZ ARTRITISZEK KÜLÖNBÖZŐ TÍPUSAI}

A kórfolyamatok patogenetikai jellege alapján az ízületi gyulladások alapvetően infekciózus (fertőzéses eredetü) és nem infekciózus csoportokra oszthatóak. Az infekciózus artritiszek kiváltásában az ízületbe különböző módon bekerült baktériumok, vírusok vagy gombák játszanak szerepet, amely folyamat általános fertőzést, szepszist is kiválthat. Gyógyításuk legfőbb eleme a kórokozók gyógyszeres elpusztításában áll. A nem infekciózus artritiszek lehetnek autoimmun betegségek, mint például a reumatoid artritisz, a gyermekkorban fellépő juvenilis idiopátiás artritisz vagy a több szervrendszert érintő poliszisztémás autoimmun kórképek. Ide soroljuk a döntően a gerincen zajló szpondiloartritiszeket, amelyek közül kiemelendő a spondilitisz ankilopoetika, a pszoriázishoz és a gyulladásos bélbetegségekhez társuló artritisz, illetve a köszvény okozta ízületi gyulladás (1. táblázat). Az alábbiakban azokat az artritiszeket ismertetjük röviden, melyek jelenleg széles körü biológiai kezelésben részesülhetnek.

1. táblázat. A gyulladásos hátterü, döntően az ízületekben zajló kórfolyamatok felosztása

- Infekciózus

- Nem infekciózus

- Autoimmun betegségek

Reumatoid artritisz

Juvenilis idiopátiás artritisz

Poliszisztémás autoimmun betegségek

- Spondiloartritiszek

Apondilitisz ankilopoetika

Artritis pszoriatica

Gyulladásos bélbetegségekhez társuló artritiszek

- Köszvény

- Egyéb, nem infekciózus artritiszek 
A reumatoid artritisz (RA) autoimmun patomechanizmusú, krónikus progresszív sokízületi gyulladás, amely az ízületek (elsősorban a kéz kisízületei) destrukciója és deformitása révén a betegek fájdalmas mozgáskorlátozottságát, rokkantságát és életminőségük jelentős romlását idézi elő. A kórkép nemcsak az ízületeket érinti, hanem gyakori belső szervi elváltozásokkal is jár, amelyek a betegek körében az átlagnépességhez képest magasabb mortalitáshoz vezetnek. Magyarországon mintegy 50 ezer személy érintettségével számolhatunk. A kórkép elsősorban a fiatal-középkorú nőket (30-50 év) érinti, a nő-férfi arány 2-3:1. A kórfolyamatban az adaptív immunitás sejtjei, elsősorban a T-helper (Th) limfociták aktiválódnak több irányban. A Th17-vonalon az autoimmunitás beindulása, a humorális Th2-n a betegségre jellemző ellenanyagok (autoantitestek) képződése (például: reumatoid faktor, antifilaggrinok) képződése, míg a celluláris Th1-vonalon a gyulladásért, porc- és csontpusztulásért felelős kóros mennyiségủ citokin (például: TNF-alfa, interleukinok stb.) termelödése történik (1. ábra).

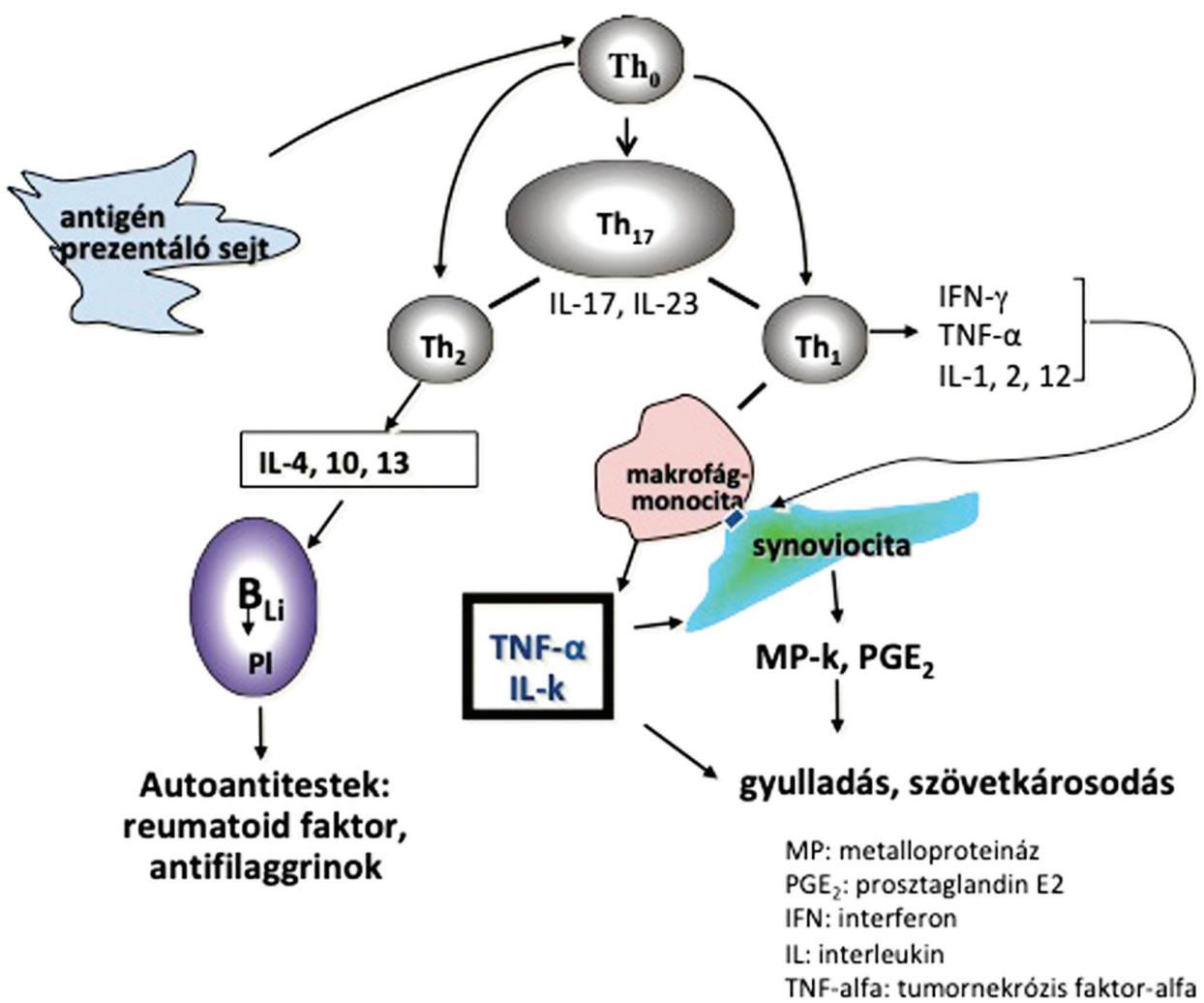

1. ábra. Az aktivált Th-sejtek szerepe az autoimmun folyamat (Th17), a humorális (Th2) immunválasz, majd a celluláris (Th1) válasz elindításában (saját szerkesztés) 
A betegség tüneti kezelésében nem szteroid gyulladásgátlókat, illetve szükség esetén szisztémásan vagy lokálisan kortikoszteroidokat adunk, önállóan csak a biztos diagnózis felállításáig. Fontos a szintetikus betegségmódosító gyógyszerek (Disease Modifying Anti Rheumatic Drugs, DMARD) minél korábbi, kellő dózisban történő alkalmazása, melyek közül kiemelkedik a metotrexát hatékonysága. Amennyiben ez nem elegendő, biológiai terápiát vezetünk be, hogy elérjük az alacsony betegségaktivitást, illetve a gyulladás klinikai megszünését jelentő remissziót. A kezelés menetét nemzetközi és hazai irányelvek szabályozzák (Poór et al., 2018; Singh et al., 2016; Smolen et al., 2017).

A juvenilis idiopátiás artritisz (JIA) a tizenhat éves kor előtt kezdődő ízületi gyulladásokat foglalja össze, melyek Magyarországon mintegy három-négy ezer fiatalt érintenek. A betegség leggyakrabban 1-3, illetve 8-12 éves korban lép fel, a JIA az élettani növekedést is gátolja. Hét alcsoportja van, melyek közül egy-egy nagyon hasonló a felnőttkori RA-hoz, az artritisz pszoriatikához vagy a szpondilitisz ankilopoetikához. Egy másik alcsoport súlyos szisztémás tünetekkel, belszervi elváltozásokkal és lázzal jár. A hatékony szintetikus és biológiai betegségmódosító kezelésekkel a betegek számára ma már a teljes élet lehetőségét tudjuk biztosítani (Otten et al., 2013).

A szpondiloartritiszek közül a szpondilitisz ankilopoetika (SPA, közismert nevén Bechterew-kór) a gerinc kisízületek, a sacroiliacalis (a keresztcsont és a csípőlapát közötti) ízületek és a szalagok többnyire szimmetrikus gyulladása, mely kiterjedt csontosodással jár együtt. Kezdete többnyire 16-30 éves korra esik, a férfi-nő arány mintegy $7: 1$. Prevalenciája $0,1-0,3 \%$, az örökletesség mértéke meghaladja a $70 \%$-ot. A betegség pontos okát nem ismerjük, abban genetikai és környezeti tényezők egyaránt szerepet játszanak. A betegség leggyakrabban gerincpanaszokkal kezdődik, a keresztcsonti és ágyéki területen bizonytalanul lokalizálható, nyugalomban erősödő, mozgásra enyhülő fájdalommal, amely az éjszaka második felében zavarja meg a beteg alvását (gyulladásos jellegü gerincfájdalom, amely eltér a nyugalomra szünő banális fájdalomtól). A gerincfájdalomhoz a gyulladásos laborparaméterek (vörösvértest-süllyedés, CRP) emelkedése társul. A HLA B27-hordozásnak diagnosztikai és prognosztikai jelentősége van. A diagnózis felállításában meghatározó a sacroileitis, melynek kimutatásában az MRI sokkal érzékenyebb a konvencionális röntgennél. A nem szteroid gyulladáscsökkentőkkel történő terápiát mielőbb meg kell kezdeni, fennmaradó aktív betegség esetén biológiai terápia indítható (Géher-Poór, 2018; van der Heijde et al., 2017).

Az artritisz pszoriatika (APs) a pszoriázishoz (pikkelysömör) társuló krónikus gyulladásos mozgásszervi elváltozások összefoglaló neve. A pszoriázis a népesség 1\%-át érinti, ezen belül mintegy 20-30\%-ban jelentkezik artritisz, ennek prevalenciája tehát $0,2-0,3 \%$. A férfi-nő arány: $1: 1$, a betegség leggyakrabban 20-40 éves kor között lép fel. A betegség különböző formái elsősorban a kéz- és lábízü- 
leteket, valamint az íntapadási helyeket érintik, de járhat a gerinc képleteinek gyulladásával is. A más kezelésre nem reagáló aktív folyamat biológiai kezelést tesz szükségessé (Gossec et al., 2015).

A köszvény (artritisz urika) alapvetően a purinanyagcsere zavara, mikor a vérben felszaporodott húgysav kristályok formájában kicsapódva ízületi gyulladást, és más belszervi szövődményt (például vese- és szív-érrendszeri károsodást) idéz elö. Az ízületi gyulladás - szemben az RA-val - nem az adaptív immunitás aktiválódásával járó autoimmun folyamat, hanem a természetes immunitás, elsősorban a fehérvérsejtek és a makrofágok fokozott müködésével és inflammaszóma képződéssel jellemezhető autoinflammatórikus gyulladás. Az autoinflammáció kulcsfontosságú citokinje, az IL1-béta biológiai kezeléssel ma már célzottan gátolható (Igel et al., 2017).

\section{AZ ARTRITISZEKBEN HASZNÁLT BIOLÓGIAI KÉSZITTMÉNYEK}

A kezelt betegek és az indikációként szereplő kórképek számát, valamint a hatékonyságot tekintve a biológiai terápia egyik legfontosabb felhasználási területe a reumatológia. Alkalmazását az immunmediált gyulladásos kórképek patomechanizmusának feltárása révén szerzett ismeretek rohamos bővülése tette lehetővé. Szakterületünk ugyanakkor a tumornekrózisfaktor-alfa RA-ban történő kulcsszerepének felfedezésével és a TNF-alfa-gátlás első alkalmazásával (infliximab) úttörőként írta be a nevét a medicina történetébe, és utat mutatott a más szakterületeken (például: bőrgyógyászat, gasztroenterológia) történő felhasználás irányába. A Ravinder Maini és Marc Feldmann által tett forradalmi felfedezés a reumatológia sikertörténetének kiemelkedő fejezete (Feldmann-Maini, 2001).

A TNF-alfa-gátlókat az RA-ban történt széles körü és eredményes alkalmazás után más reumatológiai kórképekben is sikerrel vetették be, mindazokban, ahol a TNF-alfa kórosan felszaporodott mennyisége a patogenetikai folyamatban igazolást nyert. Ilyenek az SPA, az APs és a JIA. A gyakorlatban ma is leginkább használt TNF-alfa-gátlók mellett ugyanakkor megjelentek új terápiás célpontok is, amelyek közül a klinikai alkalmazás szempontjából az interleukinok, valamint az immunsejtek, tehát T- és B-sejtek gátlása emelendő ki (2. ábra).

Az alkalmazás gyakoriságának tekintetében a biologikumok között a hazánkban több mint tíz éve eredményesen használt TNF-alfa-citokingátlók dominanciája figyelhető meg. A monoklonális ellenanyagokon $(\mathrm{mAb})$ belül az infúzióban adható infliximab, valamint a teljesen humán szubkután injekció, az adalimumab és golimumab RA-ban, SPA-ban és APs-ben egyaránt sikerrel alkalmazható. A pegilált (polietilénglikollal kapcsolt) certolizumab pegol közfinanszírozott felírhatósága jelenleg csak az RA-ra terjed ki, egyedi méltányossági kérés alapján adható SPA-ban és APs-ben is. A mAb-októl eltérő szolúbilis TNF-alfa receptor- 
Citokinek gátlása

- TNF-alfa-gátlók

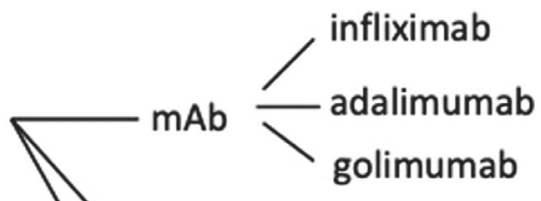

pegylált mAb - certulizumab pegol

szolubilis TNF-alfa receptor - etanercept
- Interleukin-gátlók IL-1-béta - canakinumab
IL-6R - tocilizumab
IL-17A - secukinumab

\section{Immunsejtek felszínén ható molekulák}

- B-sejtek - rituximab

- T-sejtek - abatacept

TNF=tumornekrózisfaktor, IL-R=interleukin receptor, $m A b=$ monoclonal antibody

2. ábra. A reumatológiában jelenleg használt biologikumok hatásának felosztása

(saját szerkesztés)

szerkezetü etanercept az RA, SPA, APs mellett JIA-ban is széles körben használt. Az interleukingátlók közül az RA-ban és JIA-ban hatékony, infúzióban és szubkután egyaránt adható tocilizumab az IL6-receptort, míg a szpondiloartritiszekben (SPA, APs) a közeljövőben alkalmazható secukinumab az IL17A-molekulát blokkolja. Az IL1-béta inhibitor canakinumab a köszvényes gyulladás kulcsmolekulájának gátlásával fejti ki gyors hatását. Az immunsejtek felszínén történő gátló hatást B- és T-sejtek vonatkozásában egyaránt kihasználjuk. A CD20+B-sejteket blokkoló rituximabot TNF-alfa refrakter RA-ban alkalmazzuk infúziós formában. A szubkután és infúzióban is adható abatacept a T-sejtek aktiválódásához szükséges második szignál (kostimuláció) inhibiciója révén hat, RA-ban és JIAban egyaránt bevált (Furst et al., 2013; Nam et al., 2017).

\section{A HAZAI BIOLÓGIAI TERÁPIÁS ELLÁTÁS EREDMÉNYEI}

A reumatológia terén több mint tizenkét éves biológiai terápiás ellátás mára komoly eredményeket mutathat fel. Mindez elsősorban az artritisz centrumhálózat kialakításának és színvonalas müködtetésének, valamint a finanszírozás folyamatos biztosításának köszönhető. 
Az ízületi gyulladások diagnosztikája és gyógyszeres kezelése komoly szaktudást és anyagi ráfordítást igényel, ezért az Magyarországon hatékonyan csak centralizált szakorvosi ellátás keretében volt megoldható. A megvalósítás érdekében az Országos Reumatológiai és Fizioterápiás Intézet (ORFI) Arthritis Munkacsoportja az Egészség Évtizede Népegészségügyi Program Mozgásszervi Alprogramja keretében 2003-ban az egészségügyi kormányzathoz benyújtotta „A hazai arthritis centrumhálózat felállításának tervezetét”, mely elfogadásra került (Poór, 2003). A követelményeknek országosan huszonegy hazai centrum felelt meg, és az egész rendszer irányítására Országos Felnőtt- és Gyermekreumatológiai Arthritis Központként az ORFI kapott megbízást. A hálózatban több mint százötven reumatológus és más szakorvos dolgozik az adott egyetem vagy vezetö hazai kórház reumatológiai osztálya és ambulanciája keretében. A rendszer célja az, hogy az ízületi gyulladásban szenvedők lakóhelyükhöz közel jussanak minőségi szakorvosi ellátáshoz.

A TNF-alfa-antagonista biológiai gyógyszerek hazai társadalombiztosítási támogatása 2006-ban az RA célzott kezelésével (infliximab, etanercept majd adalimumab) vette kezdetét. Ezt más artritiszek, illetve a bőrgyógyászati és a gasztroenterológiai betegségek terápiájának finanszírozása követte. A finanszírozott biológiai gyógyszerek és azok indikációs köre fokozatosan bővült, és ezáltal is a biológiai készítményekkel kezelt betegek száma 2006-tól 2018-ig folyamatosan nőtt. A 2018-ban biológiai terápiával, közfinanszírozottan kezelt betegek száma meghaladta a 12 ezer föt, akiknek több mint 70\%-a reumatológiai beteg. Sikerült elérni, hogy a szakterületünkön alkalmazott összes biologikumra az OEP/ NEAK-támogatás mértéke az elmúlt tíz évben folyamatosan 100\% legyen, ami kizárólag a centrumokban történő kezelésekre vonatkozik.

A jelen hazai biológiai terápiás helyzet európai összehasonlítása kedveért egy példával szolgálhatunk. A különböző biológiai terápián lévő összes reumatoid artritiszes beteg aránya nálunk mintegy 9\%, amivel közelítjük az Európai Unió országainak átlagát (12,5\%). A jelenlegi felhasználással jóval meghaladjuk a közép- és kelet-európai átlagot (3-4\%), ugyanakkor azt is tudnunk kell, hogy az arány Finnországban, Belgiumban vagy Ausztriában 20\% feletti, míg Norvégiában, Svédországban vagy Î́rországban 30\%-nál is magasabb (Péntek et al., 2014).

Azt is látni kell, hogy a nagyszámú artritiszes beteg a létrehozott centrumokban a személyi és tárgyi feltételek biztosításával a nemzetközi és hazai irányelveknek megfelelő, szakmailag kiemelt ellátást kap. Az artritiszes betegek kezelésére olyan európai színvonalú hálózatot sikerült kialakítani és müködtetni, ahol a betegségek adekvát korai diagnosztikája és a betegek célzott gyógyszeres kezelése megadott célértékek alapján történik (Poór, 2015). Az is vívmány, hogy az eltelt tíz év alatt minden beteg államilag finanszírozott módon jutott hozzá ahhoz a biológiai terápiás készítményhez, amelyet a kezelöorvosa számára javasolt. A felépített rendszer legnagyobb eredménye, hogy a biológiai kezelésben része- 
sült felnőtt- és gyermekkori betegek mintegy kétharmada teljesen új életminőséget és perspektívát kapott, megtapasztalta, hogy milyenek a fájdalom nélküli mindennapok, és a rokkantság helyett megőrizhette munkaképességét. Ez nemcsak az egyénnek, hanem a családnak és a társadalomnak is kiemelt fontosságú.

\section{KITEKINTÉS}

Az artritiszek kezelése terén a molekuláris forradalom folytatódása és kiterjedése várható, számos biologikum klinikai gyógyszervizsgálata előrehaladott állapotban van. Látható, hogy a TNF-alfa-gátlók fejlesztésének korszaka többnyire befejeződött, a licencek lejártát követően az originátor készítmények különböző biohasonló változatainak folyamatos és kiterjedt megjelenésére számíthatunk. A citokingátláson belül a hangsúly az interleukinokra tevődik át, ezek közül egyre több új célpont és biologikum jelenik meg majd a piacon. A távolabbi jövőben ígéretesnek tủnik a regulatórikus T-sejtek stimulálása, a dendritikus T-sejtek, illetve a zsírsejtek által termelt adipokinek blokkolása, valamint az őssejtterápia és a génterápia lehetősége is.

Bár nem tartoznak a nagy molekulájú, fehérjetermészetű biológiai gyógyszerek közé, a kis molekulákhoz sorolt célzott orális szignálgátló készítmények (a Janus-kináz, rövidítve JAK-gátló tofacitinib és baricitinib) a jövő ígéretes terápiás lehetőségeit jelenthetik. Hazai regisztrációjukat követően már a közeljövőben közfinanszírozásban részesülhetnek.

Terápiás lehetőségeink bővülésével és az artritiszben szenvedő egyén betegségének pontosabb patogenetikai feltérképezésével talán a személyre szabott gyógyítás lehetőségeit is meg tudjuk teremteni ezen a területen a jövőben.

\section{IRODALOM}

Feldmann, M. - Maini, R. N. (2001): Anti TNF-alpha Therapy of Rheumatoid Arthritis: What Have We Learned? Annual Review of Immunology, 13,163-196. DOI: 10.1146/annurev.immunol.19.1.163

Furst, D. - Breedveld, F. C. - Kalden, J. R. et al. (2013): Updated Consensus Statement on Biological Agents for the Treatment of Rheumatic Diseases, 2012. Annals of the Rheumatic Diseases, 72 (Suppl 2),112-134. DOI: 10.1136/annrheumdis-2013-203348

Géher Pál - Poór Gy. (2018): Az axialis spondyloarthritisek kezelése. Az Emberi Erőforrások Minisztériuma szakmai irányelve. Egészségügyi Közlöny, LXVIII, 969-991. http://www.hbcs.hu/ uploads/jogszabaly/2732/fajlok/EMMI_szakmai_iranyelve_axialis\%20.pdf

Gossec, L. - Smolen, J. S. - Ramiro, S. et al. (2015): European League against Rheumatism (EULAR) Recommendations for the Management of Psoriatic Arthritis with Pharmacological Therapies: 2015 Update. Annals of the Rheumatic Diseases, 74, 1-12. DOI: 10.1136/annrheumdis-2015-208337, https://ard.bmj.com/content/75/3/499.long 
Igel, T. F. - Krasnokutsky, S. - Pillinger, M. H. (2017): Recent Advances in Understanding and Managing Gout. F1000Research, 6, 247 DOI: 10.12688/f1000research.9402.1, https://www. ncbi.nlm.nih.gov/pmc/articles/PMC5357039/

Nam, J. L. - Takase-Minegishi, K. - Ramiro, S. et al. (2017): Efficacy of Biological Disease-modifying Antirheumatic Drugs: A Systematic Literature Review Informing the 2016 Update of the EULAR Recommendations for the Management of Rheumatoid Arthritis. Annals of the Rheumatic Diseases, 76:1113-1136. DOI: 10.1136/annrheumdis-2016-210713

Otten, M. - Anink, J. - Spronk, S. et al. (2013): Efficacy of Biological Agents in Juvenile Idiopathic Arthritis: A Systematic Review Using Indirect Comparisons. Annals of the Rheumatic Diseases, 72, 1806-1812. DOI: 10.1136/annrheumdis-2012-201991, https://ard.bmj.com/content/72/11/1806.long

Péntek M. - Poór Gy. - Wiland P. et al. (2014): Biological Therapy In Inflammatory Rheumatic Diseases: Issues in Central and Eastern European Countries. European Journal Health Economics, 15 (Suppl 1), 1:S35-43. DOI: 10.1007/s10198-014-0592-6, https://www.researchgate. net/publication/262382070_Biological_therapy_in_inflammatory_rheumatic_diseases_Issues_in_Central_and_Eastern_European_countries

Poór Gy. - ORFI Arthritis Munkacsoport (2003): A hazai arthritis centrumhálózat felállitásának tervezete az Egészség Évtizede Népegészségügyi Program Mozgásszervi Alprogramjának keretében. Budapest

Poór Gy. (2015): Tízéves az arthritisek biológiai terápiás ellátása Magyarországon. Magyar Reumatológia, 56, 199-207.

Poór Gy. (2018): A rheumatoid arthritis szintetikus és biológiai betegségmódosító gyógyszerekkel történő hazai kezelése az EULAR 2016-os ajánlása alapján. Az Emberi Erőforrások Minisztériuma szakmai irányelve. Egészségügyi Közlöny, LXVIII, 991-1001. http://www.hbcs.hu/uploads/jogszabaly/2730/fajlok/EMMI_szakmai_iranyelv_rheumatoid_arthritis.pdf

Singh, Jr. A. - Saag, K. G. - Bridges, S. L., Jr. et al. (2016): 2015 American College of Rheumatology Guideline for the Treatment of Rheumatoid Arthritis. Arthritis Care Research (Hoboken), 68, 1-25. DOI: 10.1002/art.39480, https://onlinelibrary.wiley.com/doi/full/10.1002/art.39480

Smolen, J. S. - Landewé, R. - Bijlsma, J. et al. (2017): EULAR Recommendations for the Management of Rheumatoid Arthritis with Synthetic and Biological Disease-modifying Antirheumatic Drugs: 2016 Update. Annals of the Rheumatic Diseases, 0, 1-18. DOI: 10.1138/annrheumdis-2016-210715, https://ard.bmj.com/content/76/6/960.long

van der Heijde, D. - Ramiro, S. - Landewé R. et al. (2017): 2016 Update of the ASAS-EULAR Management Recommendation for Axial Spondyloarthritis. Annals of the Rheumatic Diseases, 76, 978-991. DOI: 10.1136/annrheumdis-2016-210770, https://ard.bmj.com/content/76/6/978. long 